\title{
MANIFESTASI THE SACRED PADA MASYARAKAT INDONESIA: Adisi Substitusi dan Sinkretisasi
}

\author{
Yustinus Slamet Antono*
}

\begin{abstract}
Abstrak
Selain yang diajarkan dalam agama-agama resmi, setiap suku bangsa Indonesia juga memiliki keyakinan-keyakinan asli terkait dengan apa saja yang dianggap sakral (the sacred). Lebih dari itu adat-istiadat yang ditampakkan dalam upacara-upacara tradisional bisa dengan mudah dicari hubungannya dengan apa yang dianggap sakral itu. Artikel ini akan menampilkan beberapa manifestasi yang sakral dalam kehidupan sehari-hari yang sebenarnya bisa merupakan substitusi (penggantian), adisi (tambahan) dan sinkretisasi (penyesuaian, penyelarasan). Untuk memperluas sudut pandang terhadap fenomena itu, dalam artikel ini akan dihadirkan gagasan-gagasan antropolog dan sosiolog yang mendalami masalah keagamaan.
\end{abstract}

Kata-kata kunci: The Sacred, substitusi, adisi, sinkretisasi, manifestasi

\section{Fenomena Keagamaan}

James L. Cox (2006) merupakan salah seorang penulis buku yang sejak pada bagian awal menentukan posisi kajiannya di belantara kajian-kajian keagamaan. Ia berusaha menekankan kekhasan fenomenologi agama dibandingkan studi-studi lain yang di dalamnya menjadikan agama sebagai obyek formalnya. Bagi James L. Cox, kekhasan itu penting untuk ditunjukkan mengingat terdapat tokohtokoh pemikir besar yang sangat berpengaruh dalam perkembangan berbagai ilmu pengetahuan, termasuk ilmu-ilmu sosial. Sebagai implikasinya adalah terdapat kemungkinan krisis identitas suatu ilmu ketika ilmu tersebut membahas bidang kajian yang sama. Pada awal bukunya ia mengatakan: 
This book is born from a growing conviction, confirmed by my discussions with colleagues and supported by teaching in undergraduate and postgraduate courses, that religious studies, as a field midway between theology and the social and cultural sciences, suffers from a severe crisis of identity. In my view, this has resulted, at least in part, from the central role phenomenology of religions has played historically in the development of the academic study of religions ${ }^{1}$.

James L. Cox menjelaskan bahwa perkembangan studi agama-agama (the development of the academic study of religions) telah mempengaruhi perkembangan ilmu-ilmu lain (fenomenologi dan teologi). Secara tidak langsung ia menempatkan fenomenologi (agama) berada dalam rumpun studi akademis agama-agama. Dalam buku yang berjudul A Guide to the Phenomenology of Religion Key Figures, Formative Influences and Subsequent Debates itu ia memberikan penjelasan ruang lingkup fenomenologi dalam studi agama-agama.

Menyinggung tokoh-tokoh yang berpengaruh dan pada saat yang sama ia mengikuti pendapat Daniel Pals dalam bukunya Seven Theories of Religions (1996), James L. Cox menyetujui bahwa terdapat tujuh tokoh yang dipandang berpengaruh secara teoritis dalam studi agama-agama. Mereka adalah E. B. Tylor dan James Frazer, Sigmund Freud, Emile Durkheim, Karl Marx, Mircea Eliade. E. E. Evans-Pritchard dan Clifford Geertz. E. B. Tylor dan James Frazer dianggap sebagai satu kesatuan karena memiliki ide yang sama. Selanjutnya James L. Cox berpendapat bahwa tidak seorangpun dari nama-nama yang disebutkan tadi yang mengelompokkan dirinya sebagai fenomenolog. Akan tetapi James L. Cox berpendapat bahwa Mircea Eliade termasuk seorang fenomenolog, setidak-tidaknya dalam bukunya sendiri. Sebagian dari mereka lebih digolongkan sebagai antropolog kecuali Sigmund Freud

1 James L. Cox, A Guide to the Phenomenology of Religion: Key Figures, Formative Influences and Subsequent Debates (London and New York: Continuum, 2006), hlm. vii. 
Yustinus Slamet Antono, Manifestasi The Sacred pada Masyarakat Indonesia

yang mengembangkan teori Oedipus dan Karl Marx yang berbicara tentang agama dalam konteks konstruksi ideologi sosial².

Sub judul pada bagian ini adalah fenomena keagamaan. Jika diletakkan dalam konteks perbincangan mendalam tentang fenomenologi sebagai ilmu pengetahuan, terutama cakupan pembicaraannya tampaklah bahwa dari keterangan yang sudah dipaparkan bukan merupakan fenomenologi itu sendiri. Keterangan dalam sub judul pada bagian ini di satu pihak hendak mengatakan bahwa terdapat berbagai hal yang bisa diamati terkait dengan agamaagama dalam kehidupan kongkrit masyarakat baik pada masa lalu maupun pada masa kini. Di pihak lain, keterangan dengan menggunakan sub judul fenomena keagamaan hendak mempertegas bahwa agama-agama menjadi pusat pembicaraan dalam artikel ini.

Dalam etnografi, agama biasanya ditempatkan sebagai salah satu unsur kebudayaan. Unsur-unsur kebudayaan itu meliputi: nama suku bangsa, lokasi - lingkungan alam - demografi, asal-usul dan sejarah, bahasa, sistem teknologi, sistem mata pencarian, sistem organisasi sosial, sistem pengetahuan, sistem kesenian, agama dan sistem religi ${ }^{3}$. Antropologi memiliki tradisi mendeskripsikan fenomena sosial secara holistis. Melalui cara itu fenomena sosial dianggap bisa dilihat secara utuh dan bisa dicari hubungan antara unsur yang satu dengan lainnya. Banyak sedikitnya informasi yang bisa diperoleh dari unsur-unsur kebudayaan atau fenomena sosial tersebut tergantung pada tekanan atau fokus pembicaraan para antropolog atau etnolog. Dari sebab itu kita bisa menjumpai terdapat banyak definisi agama di berbagai tulisan yang kadang-kadang definisi agamanya memiliki kemiripan atau berbeda sama sekali. Terdapat dua tokoh penting yang gagasannya tentang agama mengilhami ini yaitu Emile Durkheim dan Clifford Geertz. Emile Durkheim lebih dikenal sebagai sosiolog asal Perancis dan

2 James L. Cox, A Guide to the Phenomenology of Religion: Key Figures, Formative Influences and Subsequent Debates ..., hlm. 2-3.

${ }^{3}$ Koentjaraningrat, Pengantar Antropologi I (Jakarta: Rineka Cipta, 2005), hlm. 80 . 
Clifford Geertz lebih dikenal sebagai antropolog Amerika Serikat yang pernah melakukan penelitian di Indonesia (Jawa).

\section{Yang Sakral sebagai Komponen Utama Agama}

Pada bagian terdahulu telah banyak disebut hal-hal yang dibicarakan terkait dengan agama atau dalam fenomena keagamaan. Durkheim menekankan empat hal yaitu sistem kepercayaan terkait dengan the sacred things, ritual dan komunitas ${ }^{4}$. Sementara itu Geertz lebih banyak mengedepankan unsur simbol-simbol ${ }^{5}$. Berger dan Luckmann menempatkan agama sebagai salah satu sarana yang menyediakan keteraturan, pemberi jawaban dan keteduhan terhadap kekacauan dunia, pemberi legitimasi, menyediakan nomos dan makna dari realitas dalam bentuk yang sakral.

Dalam ilmu sosial kajian keagamaan sekurang-kurangnya terkait dengan tiga hal yaitu the Sacred, ritual dan komunitas. Ketiga hal itulah yang bisa diamati secara empiris sehingga hasil kajian ilmu-ilmu sosial tersebut bisa diklarifikasi kebenarannya dalam realitas sosial. Dalam mempelajari agama-agama biasanya ilmu-ilmu sosial tidak banyak terlibat diskusi-diskusi spekulatif terkait dengan benar atau salahnya suatu ajaran agama tertentu. Diskusi semacam itu lebih menjadi perhatian para teolog. Para sosiolog dan antropolog biasanya

${ }^{4}$ Emile Durkheim mendefinisikan agama sebagai berikut: " $A$ religion is unified system of beliefs and practices relative to sacred things, that is to say, things set apart and forbbiden-beliefs and practices which unite into one single moral community called a Church, all those who adhere to them". Bdk. Emile Durkheim, The Elementary Forms of the Religious Life (New York: The Free Press, 1965), hlm. 62 .

5 Geertz mendefinisikan agama sebagai: (1) Sebuah sistem simbolsimbol yang berlaku untuk (2) menetapkan suasana hati dan motivasi-motivasi yang kuat, yang meresapi dan yang tahan lama dalam diri manusia dengan (3) merumuskan konsep-konsep mengenai suatu tatanan umum eksistensi dan (4) membungkus konsep-konsep ini dengan semacam pancaran faktualitas, sehingga (5) suasana hati dan motivasi-motivasi itu tampak khas dan realistis. Bdk. Clifford Geertz, Kebudayaan \& Agama (Yogyakarta: Kanisius, 1992), hlm. 5. 
memusatkan kajiannya pada efek atau implikasi dari ketiga komponen tadi dalam kehidupan sehari-hari.

Barangkali tidak akan ditemukan sebuah agama yang di dalamnya tidak terdapat the sacred apapun bentuk atau perwujudannya baik simbolis-empiris maupun abstrak. Demikian juga mungkin tidak akan ditemukan sebuah agama yang tidak memiliki ritual atau upacaraupacara tertentu, entah itu bersifat publik ataupun rahasia (tersembunyi). Namun, jika hanya terdapat dua hal tadi (the sacred dan ritual) belumlah bisa disebut sebagai agama sebab kedua ciri tersebut terdapat juga dalam praktek magi. Baik dalam magi maupun dalam agama terdapat kedua unsur tersebut, salah satu yang membedakan antara magi dan agama adalah terdapatnya komunitas. Oleh sebab itu mungkin juga tidak akan ditemukan suatu agama (bisa disebut begitu) jika di dalamnya tidak terdapat komunitas, yaitu mereka yang entah dengan setia atau biasa-biasa saja meyakini suatu ajaran yang berpusat pada the sacred dan terlibat entah sering atau tidak dalam ritual-ritual, baik komunal maupun personal.

Diletakkan dalam pemahaman Durkheim, aktivitas berdoa (salah satu bentuk ritual) misalnya, merupakan tindakan yang dilakukan oleh individu karena adanya tekanan eksternal karena tindakan manusia dijelaskan oleh Durkheim melalui konsep fakta sosialnya dengan pengertian bahwa fakta sosial adalah seluruh cara bertindak, baku maupun tidak, yang dapat berlaku pada individu sebagai paksaan eksternal. Durkheim menekankan faktor eksternal yang mempengaruhi tindakan individu dan unsur-unsur internal dianggap tidak berkontribusi pada tindakan individu. Jadi dalam pemikiran Durkheim secara umum bisa dikatakan bahwa aktivitas keagamaan misalnya, dilakukan oleh individu karena adanya aturan-aturan yang dibuat oleh institusi keagamaan. Aturan keagamaan itu dipandang sebagai realitas yang berada di luar individu. 


\section{The Sacred}

Sebenarnya konsep the sacred dalam bahasa Inggris dan tidak bisa diterjemahkan langsung ke dalam bahasa Indonesia: "yang sakral", "yang keramat" atau "yang Kudus" misalnya? Salah satu alasan mengapa kadang-kadang digunakan konsep atau istilah the sacred adalah kenetralan arti istilah itu. Konsep itu merujuk pada baik yang dalam manifestasinya dianggap mengandung sifat jahat (destruktif) maupun mengandung sifat baik (konstruktif) terhadap kehidupan manusia. Katakanlah seseorang atau sekelompok orang beranggapan bahwa di suatu tempat terdapat pohon beringin yang besar dihuni oleh banyak "penunggu" (sebuah istilah yang biasa digunakan). Si "penunggu" itu dianggap sering mengganggu manusia yang berada atau kebetulan melintas di sekitarnya. Jika orang ingin terbebas dari gangguan tersebut maka ia harus bersikap sedemikian rupa untuk tidak menyinggung si "penunggu" tersebut. Apabila orang itu pada akhirnya menunjukkan sikap (entah memberikan sesaji atau sekedar menunjukkan sikap tubuh yang sopan menurut adat setempat) yang "tepat", sikap itu bisa dikategorikan sebagai bentuk ritual. Dalam contoh di atas, si penunggu dalam bahasa Indonesia tidak bisa diberi label "yang Kudus". Pohon beringin besar yang dianggap terdapat banyak penghuninya tersebut juga tidak bisa diberi label "pohon yang suci". Istilah dalam bahasa Indonesia yang paling tepat untuk pohon tersebut adalah "pohon keramat". Sementara itu, terdapat banyak tempat yang dianggap sakral dan bisa atau biasa disebut sebagai tempat suci yaitu rumah-rumah peribadatan berbagai agama. Berada di tempat itu orang harus menunjukkan sikap hormat atau sekurangkurangnya sikap patut sebagaimana diharapkan oleh agama atau adat yang bersangkutan. Pembicaraan mengenai agama-agama dalam buku ini melibatkan "yang sakral" (menggunakan istilah ini sendiri sebenarnya tidak terlalu tepat karena istilah ini dalam rasa bahasa Indonesia terdapat unsur atau sifat baik) baik yang dianggap bersifat jahat maupun yang dianggap baik.

Alasan lain mengapa konsep the sacred banyak digunakan dalam artikel ini adalah karena konsep itu banyak dipakai dalam diskusidiskusi atau debat-debat ilmiah sebagaimana dilakukan oleh baik di 
kalangan sosiolog maupun antropolog. Dalam sosiologi agama istilah itu sangat populer dalam pengertian mudah dijumpai atau pasti akan dijumpai dalam setiap pembahasan mengenai agama. Pada umumnya istilah the Sacred dalam sosiologi (meminjam istilah Durkheim) dikenakan pada apa saja yang dipisahkan dari yang profan. Dengan demikian konsep itu memang lebih universal atau lebih luas dibandingkan dengan menyebut nama-nama khusus sebagaimana para pemeluk agama menyebutnya. Selain itu, pada kenyataannya di dalam agama-agama terdapat tingkatan-tingkatan kesakralan tertentu di mana perlakuan pada obyek sakral tersebut juga berbeda-beda.

\section{Adisi Substitusi dan Sinkretisasi}

Kontak kebudayaan yang berlangsung lama dan intensif antara kebudayaan yang satu dengan yang lainnya memungkinkan terjadinya perubahan-perubahan baik besar maupun kecil pada kebudayaankebudayaan tersebut. Para ahli kebudayaan menggunakan istilah akulturasi untuk menyebut keadaan seperti itu. Selanjutnya, untuk mempertajam apa yang sebenarnya sedang terjadi dalam perubahanperubahan itu para ahli kebudayaan menggunakan beberapa istilah antara lain adisi, substitusi dan sinkretisasi. Istilah yang berdekatan dengan akulturasi adalah difusi. Istilah difusi menunjuk pada penyebaran adat atau kebiasaan dari kebudayaan yang satu ke kebudayaan yang lain. Suatu kebudayaan bisa saja mengambil anasir dari kebudayaan yang lain tanpa adanya akulturasi sama sekali ${ }^{6}$.

Dalam konteks pembicaraan agama-agama, istilah adisi menunjuk pada terdapatnya tambahan-tambahan ritual (di dalamnya sebenarnya terdapat ide, gagasan, ajaran tentang yang sakral) pada adat-istiadat suatu kebudayaan tertentu sebagai akibat dari masuk atau diterimanya agama dari luar kebudayaan itu. Jika agama yang berasal dari luar itu bertahan atau bahkan semakin menyebar maka agama yang

6 Wiliam A. Haviland, Antropologi (Jakarta: Penerbit Erlangga, 1993), hlm. 263. 
datang dari luar kebudayaan itu pada akhirnya bisa menjadi milik kebudayaan asli itu dan boleh jadi akan dijadikan identitas kebudayaan atau etnis tertentu. Jika sebuah ritual tradisional berkaitan langsung dengan legitimasi dan eksistensi individu dalam masyarakat, maka bisa saja untuk sebuah acara perkawinan misalnya dilakukan dalam dua ritual: ritual tradisional dan ritual keagamaan resmi.

Substitusi menunjuk pada penggantian salah satu kebiasaan atau adat-istiadat suatu masyarakat yang hilang atau dianggap tidak sesuai lagi setelah diterimanya agama baru (dari luar). Substitusi ini biasanya terjadi pada ritual (personal dan komunal), pemimpin ritual keagamaan dan peran-peran lain yang melekat dalam diri pemimpin. Bidang lain yang bersentuhan dengan wilayah keagamaan adalah model busana. Biasanya masyarakat memiliki busana harian yang dibedakan dari busana untuk keperluan pesta dan busana untuk keperluan peribadatan. Busana harian dan busana pesta biasanya mengikuti mode yang berlaku saat itu, sementara itu busana untuk keperluan peribadatan boleh jadi cenderung tetap apabila di dalamnya terdapat unsur-unsur simbolis yang diatur oleh regulasi agama yang bersangkutan. Sangat boleh jadi busana harianpun diberi makna religius sehingga mengenakan busana tertentu diyakini sebagai bentuk kesalehan sebagaimana dituntut oleh agama yang dianutnya.

Secara luas istilah sinkretisasi (sinkretisme) menunjuk pada terdapatnya unsur-unsur lama bercampur dengan yang baru dan membentuk sebuah sistem baru. Dalam konteks pembicaraan tentang agama-agama sinkretisasi merupakan upaya penyesuaian unsur-unsur keagamaan yang datang dari luar pada kebudayaan atau adat-istiadat (keagamaan) setempat. Contoh hasil sinkretisasi ini tampak pada tulisan James Dananjaja seorang ahli folklor Indonesia. Ia mengatakan bahwa orang Jawa bukan saja telah mengambil alih mite-mite India, melainkan juga telah mengadopsi dewa-dewa serta pahlawan-pahlawan Hindu sebagai dewa dan pahlawan Jawa. Bahkan orang Jawa percaya bahwa epos Ramayana dan Mahabarata terjadi di pulau Jawa dan bukan 
Yustinus Slamet Antono, Manifestasi The Sacred pada Masyarakat Indonesia

di India7. Memaknai istilah sinkretisasi dengan tekanan pada unsur penyesuaian itu maka mudah untuk memahami berbagai bangunan sakral di Indonesia yang penampilan fisiknya memiliki ciri tradisional (asli) dan ciri-ciri lain (dari luar).

\section{Manifestasi yang Sakral}

Menurut sifatnya, yang sakral dapat dikelompokkan menjadi dua bentuk yaitu material dan non material. "Yang sakral-material" merupakan manifestasi empiris dari apa saja yang dianggap sakral atau bagian tak terpisahkan dari yang oleh masyarakat pendukungnya dipandang sakral. Sementara itu "yang sakral-non material" merupakan manifestasi dari apa saja yang dianggap sakral oleh masyarakat pendukungnya yang tidak empiris (abstrak). Sangat boleh jadi yang termasuk dalam jenis "yang sakral-non material" merupakan sesuatu yang diterima begitu saja dari generasi sebelumnya (given). Sementara itu, "yang sakral-material" bisa diyakini demikian karena telah melalui sebuah proses ritual tertentu oleh orang yang dianggap memiliki kompetensi dalam hal itu. Proses itu diberi istilah sakralisasi. Oleh sebab itu terdapat berbagai unsur material baik berupa benda hidup maupun benda mati yang sifatnya sementara dalam pengertian bahwa bendabenda empiris itu baru akan dianggap sakral hanya setelah melalui suatu proses ritual tertentu. Uraian berikut ini akan memberikan beberapa contoh yang pada umumnya mudah dijumpai pada masyarakat Indonesia.

\section{Manusia}

Manusia yang masih hidup jarang sekali yang dikategorikan sebagai the sacred thing. Sekalipun begitu terdapat orang-orang yang memiliki keistimewaan dalam hidupnya, dianggap memiliki kesaktian tertentu misalnya kemampuan menyembuhkan orang lain, kemampuan meramalkan masa depan dan lain sebagainya, boleh jadi orang semacam itu dianggap sebagai orang sakti dan masyarakat lebih menghormati

7 James Dananjaja, Folklor Indonesia Ilmu Gosip, Dongeng dan Lain-lain (Jakarta: Pustaka Utama Grafiti, 1997), hlm. 51. 
daripada orang pada umumnya. Orang yang memiliki kemampuan seperti itu boleh jadi dianggap sebagai sakral (sakti).

Perlakuan masyarakat pada manusia yang masih hidup dengan manusia yang sudah meninggal jelas berbeda. Orang yang sudah meninggal dalam konteks pembicaraan ini akan dikategorikan sebagai the sacred thing, ia akan dipisahkan dari yang profan dalam pengertian biasa-biasa saja. Pada waktu-waktu tertentu (sesuai "kalender upacara tardisional" orang mati) akan diselenggarakan upacara-upacara terhadap kematiannya. Di lingkungan masyarakat Jawa akan mudah dijumpai makam-makam tertentu yang disakralkan karena sosok yang dimakamkan di tempat itu oleh masyarakat setempat dipandang suci atau keistimewaan supernatural sejenisnya ${ }^{8}$.

Dalam Gereja Katolik, imam termasuk dalam kategori the sacred karena ia dikhususkan, disucikan melalui ritual tahbisan. Ia dibedakan dari orang awam biasa. Hanya orang yang sudah ditahbiskan menjadi imam (disucikan) boleh memimpin perayaan Ekaristi, suatu perayaan yang oleh Gereja Katolik diyakini menyucikan umatnya. Imam yang sudah disucikan tadi juga mendapatkan perlindungan dari pencemaran. Tindakan-tindakan orang yang "mencemarkan" imam tadi akan terkena sanksi yang diberi istilah sakrilegi.

\section{Benda-benda}

Pada bagian terdahulu sudah diterangkan bahwa salah satu ciri the sacred adalah dipisahkan dari yang lain (profan). Ciri lain adalah dilakukannya ritual tertentu dari si pemilik (baik individu maupun kelompok). Ritual tersebut tidak harus berupa upacara-upacara panjang tetapi bisa berupa sikap-sikap atau ungkapan-ungkapan sederhana, kata-kata atau gerak tubuh (sikap hormat, membungkuk, menyembah dan lain-lain). Oleh sebab itu tidak semua benda yang dipisahkan termasuk sebagai benda sakral, walaupun benda-benda tersebut sangat berharga dan bermanfaat dalam hidup seseorang atau sekelompok orang. Ijazah, sertifikat-sertifikat, piagam-piagam, album foto, buku-

${ }^{8}$ Bdk. Henri Chambert-Loir \& Claude Guillot, Ziarah \& Wali di Dunia Islam (Jakarta: Komunitas Bambu, 2010), hlm. 2-4. 
Yustinus Slamet Antono, Manifestasi The Sacred pada Masyarakat Indonesia

buku atau mungkin benda-benda antik adalah benda-benda yang dipisahkan dan diistimewakan, tetapi benda-benda tersebut tidak dianggap sebagai benda sakral.

Berbagai jenis benda yang dipandang sakral oleh pemiliknya banyak dijumpai dalam tulisan-tulisan yang betemakan kebudayaan Jawa. Secara umum, suatu benda dianggap sakral karena dalam benda tersebut terdapat spiritual being yang difungsikan sebagai pelindung pemiliknya. Benda-benda itu berupa aneka jenis senjata tradisional dan berbagai macam jenis jimat. Dari sebab itu berbagai benda tersebut termasuk kategori benda artifisial, artinya menjadi benda seperti yang tampak itu sebelumnya telah melalui proses baik berupa pencampuran antar benda (misalnya besi, emas, kuningan, perunggu, kuningan dan lain-lain) maupun ritual tertentu baik selama proses itu berlangsung maupun setelah berbentuk barang jadi. Dengan kata lain, benda-benda sakral tersebut tidak pernah menjadi sakral karena dirinya sendiri. Benda-benda yang dipandang sakral tersebut biasanya diwariskan pada generasi penerusnya ${ }^{9}$.

Masih dalam konteks kebudayaan Jawa, selain terdapat bendabenda yang dipandang sakral seperti telah digambarkan di atas, terdapat juga benda-benda yang walaupun tidak dipandang sebagai sakral, benda-benda tersebut sangat berpotensi menjadi obyek atau benda sakral. Benda-benda tersebut bisa berasal dari tetumbuhan atau pepohonan, yaitu benda-benda yang aneh penampilannya atau langka strukturnya. Keterangan seputar benda-benda tersebut akan dideskripsikan pada bab berikutnya.

Selain benda-benda bertuah tersebut, terdapat benda yang oleh pemiliknya diperlakukan secara khusus karena merupakan pemberian dari orang tua atau siapapun yang dianggap penting dalam hidupnya. Bagi orang itu, benda tersebut menceritakan siapa pemberinya atau seperti apa kisahnya dan boleh jadi akan menambah semangat hidupnya.

${ }_{9}$ Bdk. Capt. R.P. Suyono, Dunia Mistik Orang Jawa Roh, Ritual, Benda Magis (Yogyakarta: LkiS, 2007), hlm. 235-272. 
Diterimanya agama-agama yang berasal dari luar Jawa atau Indonesia memungkinkan terdapatnya berbagai jenis benda yang dipandang sakral setelah melalui ritual-ritual yang sudah ditentukan. Kitab Suci agama-agama (buku-buku), bagaimanapun tidak akan diperlakukan sebagai benda profan. Memperlakukan Kitab Suci tersebut secara tidak tepat akan terkena sanksi oleh komunitasnya. Bahkan, sekiranya terdapat kemiripan tulisan yang menyerupai tulisan dalam Kitab suci dan diperlakukan secara profan sudah bisa menimbulkan keonaran sosial. Jadi sudah sewajarnyalah kalau obyek sakral yang dihayati seseorang atau komunitas bertambah atau berkurang dalam religiositasnya. Alasanya, agama-agama yang datang dari luar tersebut memiliki berbagai obyek sakral baik berupa benda, orang maupun tempat-tempat, waktu dan lain-lain.

\section{Fauna}

Untuk memenuhi kebutuhan nutrisi manusia mengkonsumsi berbagai jenis hewan. Hewan-hewan tersebut antara lain kerbau, kuda, sapi, kambing, domba, ayam, burung dan lain sebagainya. Selain dikonsumsi, beberapa hewan tadi juga digunakan sebagai sarana transportasi (kerbau, kuda, sapi). Sejauh hewan tersebut digunakan sebagai sarana ritual, hewan tersebut bisa dikategorikan sebagai the sacred. Namun terdapat juga masyarakat yang menjadikan hewan tertentu sebagai the sacred bukan pertama-tama karena digunakan sebagai sarana ritual tetapi karena dianggap sebagai totem atau dianggap sebagai titisan dewa atau sebagai kendaraan dari dewa. Kemungkinan lain yang menjadikan hewan tertentu dianggap sakral adalah karena penampilan atau bentuknya yang aneh dalam pengertian binatang tersebut tidak seperti ras hewan sejenisnya atau sekedar karena kelainan genetik.

Berbagai jenis hewan: sapi terdapat juga kerbau, babi, kambing, domba, ayam, ikan dan sebagainya dianggap sakral sejauh hewanhewan tersebut menjadi bagian dari ritual misalnya sebagai bahan kurban atau persembahan. Sejumlah hewan tersebut oleh pendukung keyakinan atau agamanya, baik pengorbanan maupun jenisnya bermakna simbolik. Itulah sebabnya jika hewan-hewan tersebut 
digunakan dalam keperluan ritual, diterangkan maksud dan tujuannya. Selain hewan-hewan "sakral-kondisional" tersebut terdapat juga hewanhewan yang dianggap sakral (mungkin karena dianggap bertuah) misalnya kerbau bule, yaitu kerbau yang berwarna putih. Ayam cemani yaitu ayam yang secara keseluruhan berwarna hitam. Hewan ini juga dianggap memiliki keistimewaan. Pendeknya, terdapat syarat-syarat tertentu agar hewan tersebut masuk dalam kategori sebagai hewan sakral karena keadaannya atau hewan "sakral-kondisional" karena dijadikan bagian dari upacara ${ }^{10}$.

\section{Flora}

Di antara berbagai tumbuhan mungkin dalam lingkungan masyarakat di mana mereka hidup terdapat pohon yang dianggap sakral. Pohon tersebut diperlakukan secara berbeda dibandingkan dengan pohon-pohon lain. Pada masyarakat Jawa, pada umumnya pohon-pohon beringin yang besar dianggap menjadi tempat tinggal para makhluk halus. Boleh jadi pohon-pohon tersebut menjadi atau bisa dikategorikan sakral justru karena adanya keyakinan bahwa di pohon tersebut menjadi tempat tinggal berbagai makhluk halus tersebut. Boleh jadi terdapat cerita rakyat terkait dengan pohon tersebut yang semakin hari semakin "berwibawalah" pohon itu. Cerita itu bisa berupa kejadian-kejadian yang diandaikan pernah ada, misalnya "penampakanpenampakan" sosok penghuni pohon tersebut ${ }^{11}$.

\section{Tanah}

Salah satu suvenir yang dijual di Israel adalah tanah. Tanah itu dimasukkan ke dalam bungkusan kecil sehingga memang mudah untuk diselipkan ke dalam tas atau setidak-tidaknya tidak memenuhi tempat untuk membawa barang bawaan. Penganut agama Yahudi dan juga

10 Bdk. Capt. R.P. Suyono, Dunia Mistik Orang Jawa Roh, Ritual, Benda Magis ..., hlm. 96-98.

11 Bdk. Capt. R.P. Suyono, Dunia Mistik Orang Jawa Roh, Ritual, Benda Magis ..., hlm. 97. Bdk. Franz Magnis-Suseno, Etika Jawa sebuah Analisa Falsafi tentang Kebijaksanaan Hidup Jawa (Jakarta: Gramedia, 1984), hlm. 86-87. 
bagi orang Katolik, tanah Israel dianggap sebagai tanah suci. Itulah sebabnya orang yang pergi berziarah ke Israel akan menggunakan istilah "pergi ke tanah suci". Legitimasi terhadap kesucian tanah tersebut terdapat dalam Kitab Sucinya.

Dalam masyarakat Jawa, terdapat suatu upacara "tedhak siten". Istilah itu menunjuk pada suatu upacara bagi seorang anak kecil yang untuk pertama kalinya boleh menyentuh tanah. Di balik ide upacara tersebut terdapat keyakinan bahwa tanah merupakan tempat segala macam hal buruk bagi anak kecil. Upacara itu sendiri dimaksudkan untuk menguatkan anak dalam menghadapi bahaya-bahaya yang mungkin ditimbulkan dari tanah tersebut ${ }^{12}$.

Tanah di kompleks pemakaman oleh sebagian besar masyarakat juga dianggap sakral. Secara fisik kompleks makam tersebut dipisahkan dari tempat umum wilayah pemukiman. Cerita-cerita rakyat yang menakutkan pada seputar orang yang sudah meninggal membuat kompleks pemakaman tersebut menjadi seram. Cerita rakyat tersebut semakin menguatkan kesakralan kompleks pemakaman dan dalam arti tertentu melindungi kompleks tersebut dari tindakan-tindakan yang tidak patut. Selain itu, wilayah pemakaman juga dianggap kotor. Orang harus membersihkan diri setelah mengunjungi makam ${ }^{13}$.

Air

Air bisa menjadi obyek sakral baik bagi masyarakat. Di tempattempat ziarah Katolik, biasanya terdapat air yang dipandang suci. Peziarah biasanya membawa botol kecil atau bahkan bisa mencapai dua atau tiga liter sekaligus untuk disimpan di rumah atau dibagikan kepada tetangga.

Di samping air dianggap suci karena asal tempatnya (misalnya air dari Lourdes), air dianggap suci karena disucikan melalui ritual oleh

12 Bdk. Niels Mulder, Kebatinan dan Hidup Sehari-hari Orang Jawa Kelangsungan dan Perubahan Kulturil (Jakarta: Gramedia, 1983), hlm. 68.

13 Clifford Geertz, Abangan, Santri, Priyayi dalam Masyarakat Jawa (Jakarta: Dunia Pustaka Jaya, 1983), hlm. 32-33. 
orang yang bisa dianggap kompeten. Orang yang dianggap kompeten ini dalam Gereja Katolik adalah imam. Dalam masyarakat pada umumnya, terdapat orang yang juga dipandang berkompeten untuk "menyucikan" air atau setidaknya air itu dibuat menjadi berkasiat untuk upaya penyembuahan. Dukun atau datu adalah orang-orang yang dipandang oleh masyarakat memiliki kecakapan tersebut.

Di seputar air yang terdapat di suatu tempat dan dianggap sakral (baik tempatnya maupun airnya), biasanya terdapat cerita rakyat yang bisa dijadikan sumber legitimasi terhadap kesakralan obyek sakral tersebut. Dalam kehidupan sehari-hari, air memang lebih banyak "bersifat memberi kehidupan". Tidak ada satu makhlukpun yang hidupnya tidak didukung oleh air. Oleh manusia, air juga digunakan untuk membersihkan dan dari situ agaknya berbagai ritual pembersihan diri menggunakan air sebagai sarananya. Akan tetapi jika manusia berhadapan dengan air yang tak terbilang banyaknya dan kedatangannyapun secara tiba-tiba (air bah, banjir, tsunami), maka hanya sedikitlah orang yang mampu bertahan hidup karenanya. Air bisa menjadi contoh yang lebih jelas bahwa sebagai obyek sakral, air memang memiliki sifat ambivalensi.

\section{Minyak}

Minyak bisa berasal dari hewan maupun dari tumbuh-tumbuhan sebagai bahan dasarnya setelah melalui proses tertentu. Pada jaman sekarang berbagai jenis obat-obatan atau sarana kecantikan dibuat dalam bentuk minyak. Sifat konstruktif (menyembuhkan) minyak tampak pada proses penyembuhan. Minyak dalam dirinya sendiri memiliki ciri alamiah halus, lembut, licin.

Minyak akan menjadi obyek sakral setelah melalui ritual tertentu. Dalam Gereja Katolik minyak tertentu juga digunakan sebagai sarana penyucian (membuat suci) setelah sebelumnya disucikan oleh pejabat yang berwewenang (Uskup). Orang yang diurapi dengan minyak tersebut, dalam taraf tertentu memperoleh status suci. Jadi minyak sebagai obyek sakral lebih berperan secara simbolis daripada praktis yang jika digunakan memberi manfaat langsung (bukan simbolis) pada orang yang menggunakannya. 


\section{Tempat}

Selain tempat-tempat peribadatan agama-agama resmi, tempat yang dianggap sakral bisa ditelusuri lewat cerita rakyat (mite, legenda dan dongeng) pada masyarakat tradisional. Tempat-tempat sakral tersebut bisa ditemukan dengan menggunakan indikator bahwa tempat tersebut "dipisahkan" dan "dilindungi" sebagaimana telah diterangkan di atas. Kesakralan sebuah tempat dipengaruhi oleh berbagai unsur di dalamnya. Tempat itu bisa menjadi sakral atau dianggap sakral karena sengaja dibuat demikian melalui atau karena ritual tertentu. Suatu tempat juga bisa disakralkan oleh masyarakat karena di tempat tersebut dianggap dihuni atau ditempati oleh suatu atau berbagai makhluk supernatural (spiritual being). Barang kali jika di suatu jalan raya menjadi lokasi kecelakaan berulang-ulang, tempat tersebut akan diberi label sebagai tempat angker. Terkait dengan berbagai peristiwa itu mungkin bisa dicari penjelasan ilmiahnya. Namun biasanya di seputar tempat tersebut, terdapat cerita rakyat yang memberi penjelasan mengapa berbagai kecelakaan itu terjadi.

Tempat-tempat yang dianggap sakral lainnya adalah perempatan jalan, situs-situs candi, mata air, danau, rumah tua, bekas pabrik, kompleks pemakaman, hutan, gunung, bukit, batu-batu besar, pantai, laut dan lain sebagainya. Indikator yang bisa dipakai untuk mengetahui apakah tempat tersebut dianggap sakral atau tidak antara lain adalah terdapatnya atau dilakukannya ritual tertentu misalnya sesaji pada tempat tersebut. Jika indikator seperti itu yang didapatkan maka kesakralan tempat itu lebih disebabkan oleh adanya anggapan bahwa di tempat tersebut dikuasai oleh makhluk supernatural ${ }^{14}$.

\section{Waktu}

Dalam kehidupan sehari-hari waktu bisa dilihat dari sisi kuantitas (kronologis) dan dari sisi kualitas (saat). Waktu bisa dikatakan sebagai waktu kuantitatif (kronologis) jika menunjuk langsung misalnya

${ }_{14}$ Bdk. Capt. R.P. Suyono, Dunia Mistik Orang Jawa Roh, Ritual, Benda Magis ..., hlm. 195-219. 
pukul 12.00. Sementara itu jika seseorang menggunakan istilah: pada saat, suatu ketika, setelah ini, sebelum malam tiba, menjelang pagi dan lain sebagainya, waktu yang sedang ditunjuk tersebut adalah waktu kualitatif.

Upacara-upacara keagamaan biasanya diselenggarakan pada waktu-waktu yang telah ditentukan berdasarkan perhitungan yang bersifat kronologis. Artinya, dalam kurun waktu satu tahun mungkin terdapat hari atau tanggal, minggu, bulan tertentu yang digunakan untuk menyelenggarakan upacara keagamaan. Pada agama-agama besar perhitungan waktu tersebut merupakan bagian dari ritual tetap dan merupakan bagian dari ajaran agama tersebut. Mengapa waktuwaktu tertentu itu yang ditentukan untuk melakukan upacara, alasanalasannya bisa dicari dari ajaran agama yang bersangkutan. Boleh jadi waktu yang dipilih adalah waktu kronologis, boleh jadi juga waktu yang ditentukan adalah waktu kualitatif atau gabungan dari keduanya. Terdapatnya waktu khusus untuk melakukan upacara atau tindakan tertentu tersebut menjadi tanda bahwa terdapat waktu sakral, yaitu waktu yang dipisahkan dari waktu-waktu lain. Mungkin juga ditetapkan semacam tuntutan sikap yang tepat sebagaimana diharapkan oleh agama yang bersangkutan atau oleh adat-istiadat yang berlaku. Misalnya, pada hari tertentu orang tidak boleh berjalan melebihi satu kilometer, pada hari-hari tertentu orang tidak boleh bekerja.

Sejauh "waktu khusus" itu dikenakan bagi semua pengikut suatu agama atau kepercayaan tertentu, maka waktu tersebut bisa dikategorikan sebagai waktu komunal. Dalam prakteknya terdapat juga waktu-waktu khusus yang bersifat personal, misalnya hari ulang tahun kelahiran, hari peringatan kematian dan lain-lain. Bagi orang yang bersangkutan, hari-hari tersebut akan diperlakukan secara khusus, dibedakan dari hari-hari biasa. Dalam konteks pembicaraan ini, waktu seperti itu bisa disebut sebagai waktu sakral personal. Perhelatan besar misalnya hari perkawinan biasanya ditentukan dengan mempertimbangkan waktu komunal dan waktu personal. Bagi masyarakat tradisional perhitungan seperti itu dianggap penting karena mungkin diyakini akan berdampak pada kehidupan selanjutnya. Oleh karena itu dalam masyarakat tradisional bisa ditemukan orang-orang 
yang secara khusus memiliki kemampuan untuk menentukan waktu yang baik bagi yang akan menyelenggarakan acara tertentu ${ }^{15}$.

\section{Kesimpulan}

Manifestasi yang sakral dalam kehidupan sehari-hari masyarakat Indonesia memiliki sejarah panjang. Sebelum agama-agama besar masuk dan diterima oleh masyarakat Indonesia, masyarakat di kepulauan Nusantara telah memiliki kepercayaan asli atau kepercayaan tradisional sendiri. Kepercayaan tradisional itu langsung terkait dengan eksistensi masyarakat yang bersangkutan. Masuknya agama-agama dari luar Indonesia tidak dengan sendirinya menghapuskan kepercayaan lama dalam kaitannya dengan manifestasi yang sakral. Adisi, substitusi dan sinkretisasi merupakan variasi-variasi mekanisme perubahan yang bisa digunakan untuk memahami manifestasi yang sakral seperti yang ada hingga saat ini. Manifestasi-manifestasi yang sakral itu masih terbuka pada perubahan-perubahan berikutnya seiring dengan terjadinya perubahan-perubahan lain pada masyarakat terutama karena berkembangnya ilmu pengetahuan dan teknologi.

$$
===0000===
$$

15 Purwadi, Petungan Jawa Menentukan Hari Baik dalam Kalender Jawa (Yogyakarta: Buku Pinus, 2006), hlm. 23-57. 
Yustinus Slamet Antono, Manifestasi The Sacred pada Masyarakat Indonesia

\section{DAFTAR PUSTAKA}

Chambert-Loir, Henri \& Claude Guillot, Ziarah \& Wali di Dunia Islam Jakarta: Komunitas Bambu, 2010.

Cox, James L, A Guide to the Phenomenology of Religion: Key Figures, Formative Influences and Subsequent Debates, London and New York: Continuum, 2006.

Dananjaja, James, Folklor Indonesia Ilmu Gosip, Dongeng dan Lain-lain, Jakarta: Pustaka Utama Grafiti, 1997.

Durkheim, Emile, The Elementary Forms of Religious Life, New York: The Free Press, 1965.

Geertz, Clifford, Abangan, Santri, Priyayi dalam Masyarakat Jawa, Jakarta: Dunia Pustaka Jaya, 1983. Kebudayaan \& Agama, Yogyakarta: Kanisius, 1992.

Haviland, Wiliam A., Antropologi, Jakarta: Penerbit Erlangga, 1993.

Koentjaraningrat, Pengantar Antropologi I, Jakarta: Rineka Cipta, 2005.

Mulder, Niels, Kebatinan dan Hidup Sehari-hari Orang Jawa Kelangsungan dan Perubahan Kulturil, Jakarta: Gramedia, 1983.

Purwadi, Petungan Jawa Menentukan Hari Baik dalam Kalender Jawa, Yogyakarta: Buku Pinus, 2006.

Suseno, Franz Magnis, Etika Jawa sebuah Analisa Falsafi tentang Kebijaksanaan Hidup Jawa, Jakarta: Gramedia, 1984.

Suyono, Capt. R.P, Dunia Mistik Orang Jawa Roh, Ritual, Benda Magis, Yogyakarta: LkiS, 2007. 